Jpn J Electroph $1994 ; 38: 95$

[原著]

\title{
Single strand conformation polymorphism (SSCP)
}

\author{
パターンに及ぼす泳動条件の影響
}

\section{前川真人*・須藤加代子** ・ Dilip Chandra Dey* ・ 小谷一夫*・菅野剛史 ${ }^{*}$}

\begin{abstract}
SUMMARY
We investigated the effects of electrophoretic gels, buffers or temperature on SSCP pattern by an automated electrophoretic system, Phast System. The electrophoresis on the $12.5 \%$ homogeneous gel gave the greatest difference in the mobility shift by genetic mutation. The SDS-containing buffer increased the resolution of each band as well as the sensitivity of detection in most cases. However, for certain mutated sequences, the native buffer was superior at detecting mutations. The mobility shift is also temperature dependent irrespective of native or SDS buffer condition. In any new mutation sequences, it is difficult to determine which is the better condition to detect the mutations, SDS or native buffer; however, the SDS-containing buffer may lead to a better sensitivity of detection. In conclusion, it is important to perform SSCP analysis under SDS buffer condition as well as native buffer condition in all cases.
\end{abstract}

Key words : polymerase chain reaction (PCR), single strand conformation polymorphism (SSCP), genetic mutation, SDS, temperature.

\section{緒言，}

遺伝子の変異部位を同定するためには, 最終的には塩 基配列の決定が必要であるが，単一の遺伝子であっても すべての塩基配列を決定するのは多大な労力を必要とす る. そてで，変異のある部位を限定するためのスクリー ニング的な手法が有用である. single strand conformation polymorphism (SSCP) 分析 ${ }^{1}$ は, その一つで, 簡便 性などの利点から現在最む頻用されている手法であり, single strand (ss) DNA の 3 次構造の変化をとらえよ うとするものである.われわれ屯遺伝性変異を検出する ためのフローチャートに SSCP 分析によるスクリーニン
グを加えている2゙.しかし原法 ${ }^{1)}$ では放射性同位元素を 用いるため，われわれは放射性同位元素を用いず銀染色 で検出する方法を考案し, ファルマシア社製の全自動電 気泳動装置ファストシステムに適用し, 乳酸脱水素酵素 (lactate dehydrogenase; LDH : EC.1.1.1.27) の遺伝 子变異をみいだすととに成果を上げている3 ${ }^{3-5)}$.しかし SSCP の泳動パターンは対象とするDNA フラグメント の塩基配列に依存はするが，逆に塩基配列からどのよう な3 次構造, 泳動パターンをとるかという予測は現時点 では不可能である.てれは, ssDNA のとりうる 3 次構 造が種々の泳動条件によって変化するためと考えられ， 実際, 泳動温度, グリセロールの有無などにより泳動パ

Effect of electrophoretic conditions on single strand conformation polymorphism (SSCP) pattern.

* Masato Maekawa, Dilip Chandra Dey, Kazuo Kotani, Takashi Kanno; 浜松医科大学臨床検査医学

** Kayoko Sudo; 東京慈恵会医科大学第三病院臨床検査医学

Correspondence address : Masato Maekawa, Department of Laboratory Medicine, Hamamatsu University School of Medicine, Handa-cho 3600, Hamamatsu 431-31, Japan.

(受付 1993 年 9 月 13 日, 受理 1993 年 10 月 18 日)

略号 : SSCP, single strand conformation polymorphism; SDS, sodium dodecyl sulfate; LDH, lactate dehydrogenase; $\mathrm{CHE}$, cholinesterase; ss, single strand; ds, double strand; EDTA, ethylene diamine tetraacetate. 
ターンは変化すると報告されている1,6 9). 今回われわれ は，泳動条件の再現性が高いと考えられるファストシス テムを用いて，ゲル濃度，バッファーの種類（native， SDS 加), 温度の泳動パターンに及ぼす影響について検 討した.

\section{方法}

\section{1. 対 象}

われわれが塩基配列を決定して明らかとなった LDH$\mathrm{A}, \mathrm{B}$ 遺伝子の変異 ${ }^{3-5,10 \sim 12)}$, butyrylcholinesterase (CHE) 遺伝子の変異 ${ }^{13)}$ のあるエクンン領域を PCR 増 幅した DNA を以下の SSCP 分析の対象とした.

\section{SSCP 分析}

PCR 增幅した DNA とホルムアミド含有溶液（95\% formamide, $20 \mathrm{mM}$ EDTA, $0.05 \%$ bromophenol blue, $0.05 \%$ xylene cyanol) を等量混合し, $80^{\circ} \mathrm{C}$ で熱変性さ せ ssDNA とした溶液をファストシステムを用いてポリ アクリルアミドゲルを支持体として電気泳動を行った. 泳動後, 同システムの development unit により銀染色 を行い， ssDNA および dsDNA を検出した ${ }^{3)}$. なお泳 動用ゲルとしては，7.5\%，12.5\% homogeneous gel, 8〜25\% gradient gel 用い, native および SDS 含有の buffer strip で泳動し, ss および double strand (ds) DNA の泳動パターンを比較検討した. との buffer strip は, 3\% charge-balanced agarose をベースに SDS 含有のもの (以下 SDS と略す) は $0.2 \mathrm{M}$ Tris-tricine buffer, pH 8.1,0.55\% SDS, native は $0.88 \mathrm{M} \mathrm{L-}$ alanine, 0.25 M Tris, pH 8.8 の泳動用バッファー溶液 を含んでいる．ゲルの種類，濃度による違いをみるため に，まず泳動温度は暫定的に $15^{\circ} \mathrm{C}$ 亿設定して電気泳動 を施行した. ついで, $12.5 \%$ homogeneous gel につい てょり詳細に, 温度による泳動パターンの違いについて 検討すべく, $5^{\circ} \mathrm{C}, 10^{\circ} \mathrm{C}, 15^{\circ} \mathrm{C}, 20^{\circ} \mathrm{C}$ と泳動温度を変化 させて SSCP 分析を施行した.

分離された ssDNA を湿潤したゲルから外科用メス で切り出し, 再 PCR によって増幅し, 得た DNA を直 接塩基配列決定した。

\section{結 果}

\section{1. 泳動支持体・泳動バッファーの違いによる泳動 パターンの変化}

Fig. 1, Table 1 にゲルの違い, 泳動バッファーの違 いによる泳動パターン, 検出効率について示した. 8〜 $25 \%$ gradient gel は, 全体的にバンドがシャープで,
泳動距離が短いにもかかわらず微細な泳動パターンの違 いをとらえることができた。また, gradient gel の特徽 として，広い範囲を同時に観察するととができ， ssDNA だけでなく dsDNA の泳動パターンの変化を1枚のゲ ルで同時に観察できた．しかし一方では，変異による移 動度の差は小さく, ヘテロの変異はダブルのバンドから 判定できてあ木モの変異ではわかりにくい傾向にあった (LDH-B 4, R $173 \mathrm{H}$; CHE 4, A 539 Y).

Homogeneous gel では, 泳動距離を伸ばしたほうが, 異なった移動度はその差を広げ変異を検出しやすくなっ た. ゲルの濃度は， $12.5 \%$ のほうが $7.5 \%$ よりも，バ ンドがシャープで, 変異の検出, 既知の変異との比較検 討に有効であった。

変異例ごとに native, SDS のいずれが至適かは異 なっており, LDH-A 7 変異 (E $328 \mathrm{U})$ は native が明 らかに有効で, 逆に LDH-B 4 (Y $147 \mathrm{U}$ ) は SDS, 他の 変異についてあ SDS のほうが劇的な異常パターンが観 察された，打抢むね，バッファーが同じであれば，いず れのゲルを用いてあ本質的な泳動パターンの形成に類似 性を認めた. ただ，分離の善し悪しがゲル濃度に依存し ていると考えられた。

検出率は, ゲルの種類別では $12.5 \%$ homogeneous gel が最も検出率が高く, $90 \%$ に近かった．また，SDS のほうが native よりも検出率は高かった。 一方では, 各エクンン別の検出率をみると，泳動する DNA 断片 が短いほざ検出率がよい傾向があった。たとえば， CHE のエクソン 4 は，いずれのゲルであ，またいずれ の泳動条件であ变異が検出された（Table 1).

\section{2. 温度変化の泳動パターンへの影響}

温度変化に伴って native, SDS，いずれのバッ ファーでも泳動パターンが大きく変化した (Fig. 2). 検 出効率は, 温度により異なっていたが, 他に変異・バッ ファーの種類む関連していた. native では $5^{\circ} \mathrm{C}$ むし くは $10^{\circ} \mathrm{C}$ で効率がよく, $20^{\circ} \mathrm{C}$ は良好な分離が得られな かった. 一方, $\operatorname{SDS}$ は $10^{\circ} \mathrm{C}$ あしく $15^{\circ} \mathrm{C}$ が検出効率 として高かった (Table 2). native バッファーでの 泳動のほうが, 検出率に温度の影響が強くみられた. 变 異の種類からみると, LDH-A 7, E 328 U の変異につい ては SDS バッファーではいずれの温度でも検出は困難 であった. 一方, LDH-B 3, 2 bp の欠落は, native バッファーを使用した場合， $5^{\circ} \mathrm{C}$ では検出できるむのの SDS に比較して劣っていた.

3. ゲルから切り出した後の SsDNA の塩基配列決定 SSCP 法で異常パターンを示した ssDNA バンド 
$\begin{array}{cc}7.5 \% & 12.5 \% \\ \text { homogeneous } & \text { homogeneous }\end{array}$

$8-25 \%$

gradient

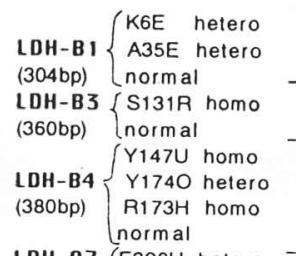

LDH-A7 $E 328 \mathrm{U}$ hetero (313bp) \{R314C hetero

CHE 4

(266bp) A539Y hetero A539Y homo
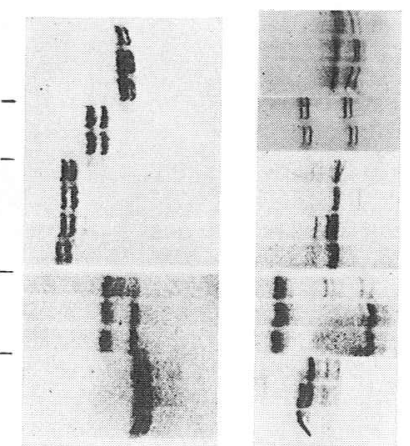

LDH-B 1 $2 \begin{cases}\text { K6E } & \text { hetero } \\ \text { A35E hetero } \\ \text { normal }\end{cases}$

LDH-B3 S131A netero

(360bp) Inormal

LDH-B4 $\left\{\begin{array}{l}Y 147 U \text { homo } \\ Y 1740 \text { hetero }\end{array}\right.$

(380bp) $\mathrm{R} 173 \mathrm{H}$ homo

LDH-A7 (E328U hetero

(313bp) $\{$ R314C hetero

CHE 4

(266bp) $\left\{\begin{array}{l}\text { A539Y hetero } \\ \text { A539Y homo }\end{array}\right.$ A539Y homo
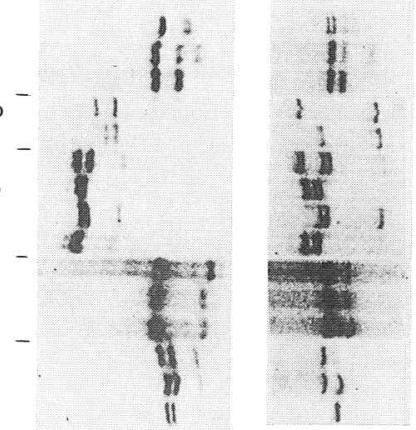

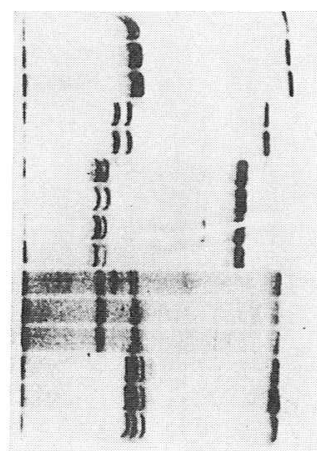

NATIVE

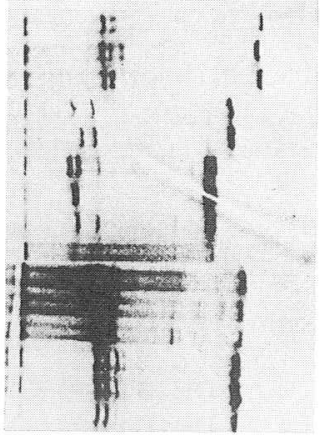

SDS

Fig. 1. Effect of different electrophoretic gels and different buffers on SSCP electrophoresis. PCR products containing genetic mutations were subjected to SSCP analysis, using $7.5 \%$ or $12.5 \%$ homogeneous gel, or $8-25 \%$ gradient gel. Buffers used native and SDS. Stained bands show ssDNA on two homogeneous gels. On $8-25 \%$ gradient gel, stained bands with slower mobility are ssDNA and those with faster mobility are dsDNA. Anode is to the right.

Table 1. Sensitivities in detecting genetic mutations with different electrophoretic media and with different buffer solutions.

\begin{tabular}{|c|c|c|c|c|c|c|c|c|}
\hline \multirow{2}{*}{ Mutation } & \multirow{2}{*}{ Gene, Exon } & \multicolumn{3}{|c|}{ Native } & \multicolumn{3}{|c|}{ SDS } & \multirow{2}{*}{$\begin{array}{c}\text { No. of cases } \\
\text { detected }\end{array}$} \\
\hline & & 7.5 & 12.5 & $8-25$ & 7.5 & 12.5 & $8-25$ & \\
\hline $\mathrm{Y} 147 \mathrm{U}(\mathrm{TA} \mathrm{T} \rightarrow \mathrm{TA} \mathrm{G})$ & L D H-B $4(380 \mathrm{bp})$ & - & - & - & + & + & + & 3 \\
\hline $\mathrm{R} 173 \mathrm{H}(\mathrm{C} \mathrm{G} \mathrm{C} \rightarrow \mathrm{C} \mathrm{A} \mathrm{C})$ & L D H-B 4 (380 bp) & - & + & + & + & + & + & 5 \\
\hline $\mathrm{Y} 174 \mathrm{O}(\mathrm{TAC} \rightarrow \mathrm{TAA})$ & L D H-B $4(380 \mathrm{bp})$ & - & + & + & - & + & - & 3 \\
\hline $\mathrm{S} 131 \mathrm{R}(\mathrm{A} \mathrm{G} \mathrm{T} \rightarrow \mathrm{C} \mathrm{G} \mathrm{T})$ & L D H-B $3(360 b p)$ & - & + & - & + & + & + & 4 \\
\hline E $328 \mathrm{U}(\mathrm{GA} \mathrm{G} \rightarrow \mathrm{TA}$ G) & L D H-A 7 (313 bp) & + & + & + & - & - & - & 3 \\
\hline $\mathrm{K} \quad 6 \mathrm{E}(\mathrm{AAA} \rightarrow \mathrm{GAA})$ & L D H-B 1 (304 bp) & - & + & + & + & + & + & 5 \\
\hline A $35 \mathrm{E}(\mathrm{G} \mathrm{C} \mathrm{G} \rightarrow \mathrm{GA} \mathrm{G})$ & L D H-B1 (304 bp) & - & + & - & + & + & + & 4 \\
\hline $\mathrm{A} 539 \mathrm{Y}(\mathrm{G} \mathrm{CA} \rightarrow \mathrm{A} \mathrm{CA})$ & C H E $\quad 4(266 \mathrm{bp})$ & + & + & + & + & + & + & 6 \\
\hline \multicolumn{2}{|c|}{ No. of cases detected } & 2 & 7 & 6 & 6 & 7 & 7 & \\
\hline
\end{tabular}

+ stands for detectable mutation.

Electrophoretic gels used are 7.5\% homogeneous gel, 12.5\% homogeneous gel, and 8-25\% gradient gel. 


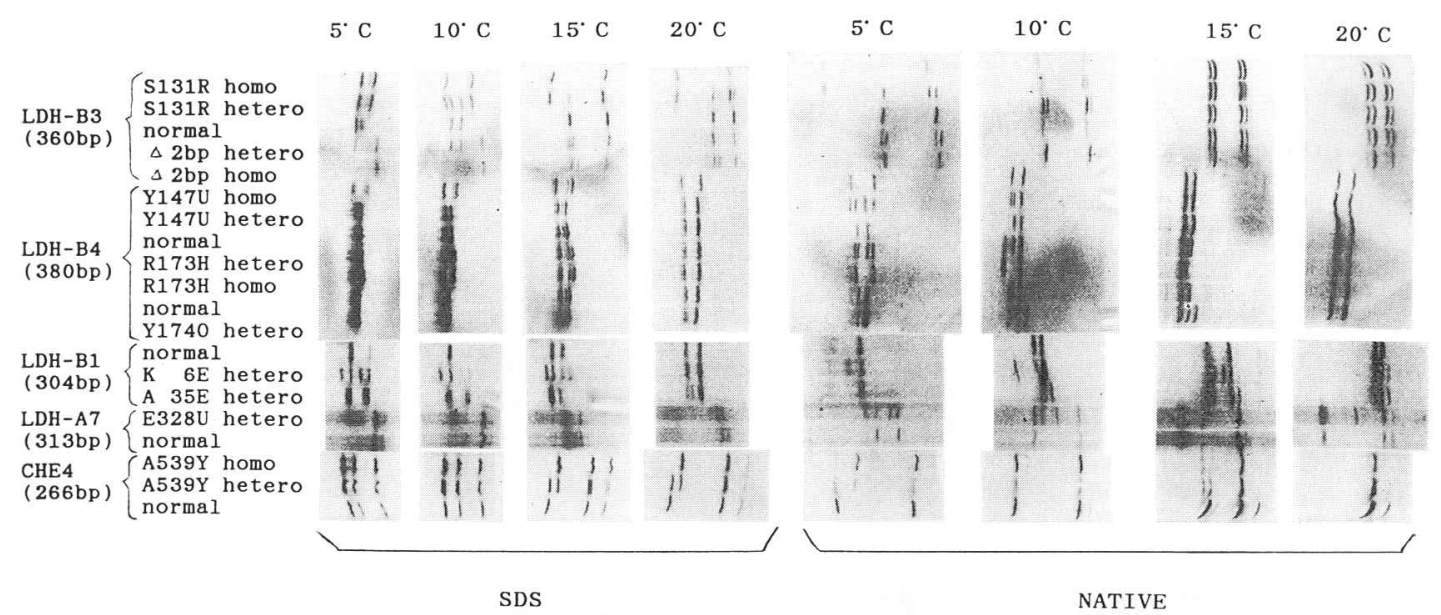

Fig. 2. Effects of different temperatures and different buffers on SSCP electrophoresis.

PCR products were subjected to SSCP analysis using $12.5 \%$ homogeneous gels, and SDS or native buffer.

Electrophoretic temperature was set at $5,10,15$ or $20^{\circ} \mathrm{C}$ by Phast System programming. Anode is to the right.

Table 2. Effect of temperature on the sensitivity for detection of genetic mutations.

\begin{tabular}{|c|c|c|c|c|c|c|c|c|c|c|}
\hline \multirow{2}{*}{ Mutation } & \multirow{2}{*}{ Gene, Exon } & \multicolumn{4}{|c|}{ Native } & \multicolumn{4}{|c|}{ SDS } & \multirow{2}{*}{$\begin{array}{c}\text { No. of cases } \\
\text { detected }\end{array}$} \\
\hline & & $5^{\circ} \mathrm{C}$ & $10^{\circ} \mathrm{C}$ & $15^{\circ} \mathrm{C}$ & $20^{\circ} \mathrm{C}$ & $5^{\circ} \mathrm{C}$ & $10^{\circ} \mathrm{C}$ & $15^{\circ} \mathrm{C}$ & $20^{\circ} \mathrm{C}$ & \\
\hline $\mathrm{Y} 147 \mathrm{U}(\mathrm{TA} \mathrm{T} \rightarrow \mathrm{TAG})$ & LDH-B 4 (380 bp) & + & + & - & - & + & + & + & + & 6 \\
\hline $\mathrm{R} 173 \mathrm{H}(\mathrm{C} \mathrm{G} \mathrm{C} \rightarrow \mathrm{CA} \mathrm{C})$ & LDH-B 4 (380 bp) & + & + & + & - & + & + & + & - & 6 \\
\hline $\mathrm{Y} 174 \mathrm{O}(\mathrm{TAC} \rightarrow \mathrm{TAA})$ & LDH-B 4 (380 bp) & + & + & + & - & - & + & + & - & 5 \\
\hline $\mathrm{S} 131 \mathrm{R}(\mathrm{A} \mathrm{G} \mathrm{T} \rightarrow \mathrm{C} \mathrm{G} \mathrm{T})$ & LDH-B 3 (360 bp) & + & + & + & - & + & + & + & + & 7 \\
\hline$\Delta 2 \mathrm{bp}(\mathrm{T} \mathrm{T} \mathrm{C} \mathrm{C} \rightarrow \mathrm{T} \mathrm{C})$ & LDH-B 3 (360 bp) & + & - & - & - & + & + & + & + & 5 \\
\hline $\mathrm{E} 328 \mathrm{U}(\mathrm{GA} \mathrm{G} \rightarrow \mathrm{TA} \mathrm{G})$ & LDH-A 7 (313 bp) & + & + & + & + & - & - & - & - & 4 \\
\hline $\mathrm{K} \quad 6 \mathrm{E}(\mathrm{AAA} \rightarrow \mathrm{GAA})$ & LDH-B 1 (304 bp) & + & + & + & + & + & + & + & + & 8 \\
\hline A $35 \mathrm{E}(\mathrm{G} \mathrm{C} \mathrm{G} \rightarrow \mathrm{GA}$ G) & LDH-B 1 (304 bp) & - & + & + & + & + & + & + & + & 7 \\
\hline $\mathrm{A} 539 \mathrm{Y}(\mathrm{GCA} \rightarrow \mathrm{ACA})$ & CHE 4 (266 bp) & + & + & + & + & + & + & + & + & 8 \\
\hline \multicolumn{2}{|c|}{ No. of cases detected } & 8 & 8 & 7 & 4 & 7 & 8 & 8 & 6 & \\
\hline
\end{tabular}

+ stands for detectable mutation.

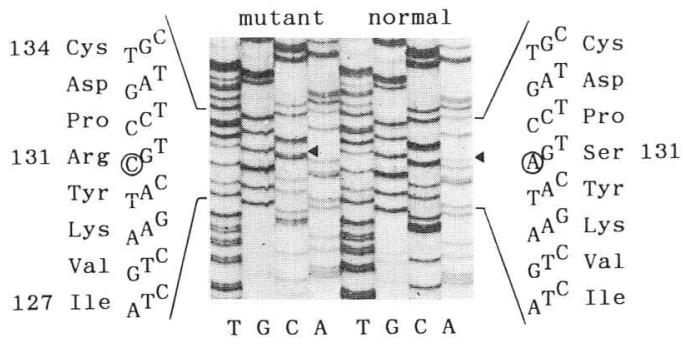

Fig. 3. Direct sequencing of the re-amplified exon 3 of LDH-B gene (a case of LDH-B variant with S 131 R mutation).

Abnormal migration bands found by SSCP analysis were cut from the Phast Gel, re-amplified by PCR, and directly sequenced. Circles and triangles show the positions of mutation.
(LDH-B 3, S 131 R) をゲルから切り出し, 再 PCR 後直 接塩基配列決定を行った. 切り出したバンドから PCR が成功しさえすれば，塩基配列決定法がそのまま適用で き, Fig. 3 に示したようにAからCへの変異が判明した.

\section{考察}

SSCP 原法は, 放射性同位元素でラベルしたサンプル (DNA) を大きなサイズのポリアクリルアミドゲル・プ レートを支持体として，ファンで泠却し温度コントロー ルをしながら泳動している。検出感度, 再現性に影響を 与えうる因子考慮し各ステップを検討すると，まずサ ンプル DNA をラベルする段階で, そのラベルの種類に より泳動パターンが変化する ${ }^{14)}$. 次に泳動用のゲルの組 
Jpn J Electroph 1994; $38: 99$

成 ${ }^{11}$ ・濃度 (高濃度のほうが分離良好 ${ }^{15}$ ) , 泳動温度 ${ }^{1,6 ~ 9)}$ などが異なれば泳動パターンは大きく異なる。乙れら泳 動条件を検討する上で, 再現性は非常に大きな問題であ る.今回用いたファストシステムは既製のゲル・バッフ アーを使用した全自動泳動装置であり，検討した種々の 条件のなかでも，同じプログラムで同一条件で同一のサ ンプル (PCR 増幅産物) を泳動した場合, ほぼ同じ結果 が得られ，再現性の点できわめて良好であった。このよ うな特徵を有するファストシステムを用いて SSCP 泳 動パターンに及ぼす影響を検討した結果，泳動用ゲルは ssDNA の泳動パターンを評価するには 12.5\% homogeneous gel がよいと判明した. 既報3,16,17)のように, dsDNA にのみ異常を示したり, dsDNA のほうが異常 の検出の容易な変異を対象とする場合, ssDNA, dsDNA を同時化評価できる 8〜25\%, gradient gel が有利と考 えられる. 温度およびバッファーの種類は変異検出の至 適条件に対して相互に関連しており，とくに native で は温度による影響を強く受けていた。

SDSは陰イオン性界面活性剂の代表的なもので膜タン パクの可溶化・単離や，タンパクと結合して一定の負の 電荷をむたせ, 分子量推定のためのポリアクリルアミド ゲル電気泳動に用いられているが, DNA の電気泳動に は用いられていない. SSCP 法でしばしば用いられるグ リセロールは，その分離能に及ばす作用は明らかではな いが, 弱い変性作用のため折り瞉まれた 3 次構造汇変化 が生じた変異部位が露出しやすくなり移動度に影響しや すくなると考元られている9 . 今回用いた SDS 屯, 泳動 中のss DNA との相互作用により 3 次構造に影響を与え
ている屯のと考えられる，そして，LDH-B 4 の変異の ように泳動パターンが native と比較してバンドが多い 例む存在した。乙れは，SDS が存在しているゅえにラ ンダムコイルになりやすいため, 一つの配列でいくつか の構造をとりやすくなり, 塩基配列の少しの違いがいず れかのバンドの構造に影響を与えるため, 検出効率の上 昇につながったと考えられる。しかし SDS の作用も現 象論であり，確かな理由は定かではない．

ファストシステム専用泳動ゲル (Phast Gel) は小さい が，全体的にバンドが㠜縮され細いバンドを形成するた め，微細な違いが判定できた。したがって，大きなゲル に十分匹敵するあのと考元られた。しかし一方では，フ アストシステムがなくとも通常のポリアクリルアミド電 気泳動装置があれば，銀染色法で検出するととにより手 軽に SSCP 分析がでさるあのと考えられる. 試みとし て，第一化学薬品社製の $12.5 \%$ homogeneous gel (約 $9 \times 9 \mathrm{~cm})$ で native, SDS の両条件で低温室で $30 \mathrm{~mA} の$ 定電流で泳動，同社の銀染色キットを用いて検出した ところ，変異を有する各バンドの同定がほぼ可能であっ た(Fig. 4). また, ファストシステムで得られた結果と 同様に SDS の泳動条件のほうが異常の検出に優れてい ると考えられた。

SSCP 法の別の面での応用としてへテロな異常老容易 に解析することができた。すなわち，異常なバンドを独 立して切り出すととができ机ば，へテロな異常でもホモ の異常に変換して解析することができる，銀染色で目で みえるそのバンドを切り出すのは，オートラジオグラ フィーでフィルムとゲルを照らし合わせて行うより明ら

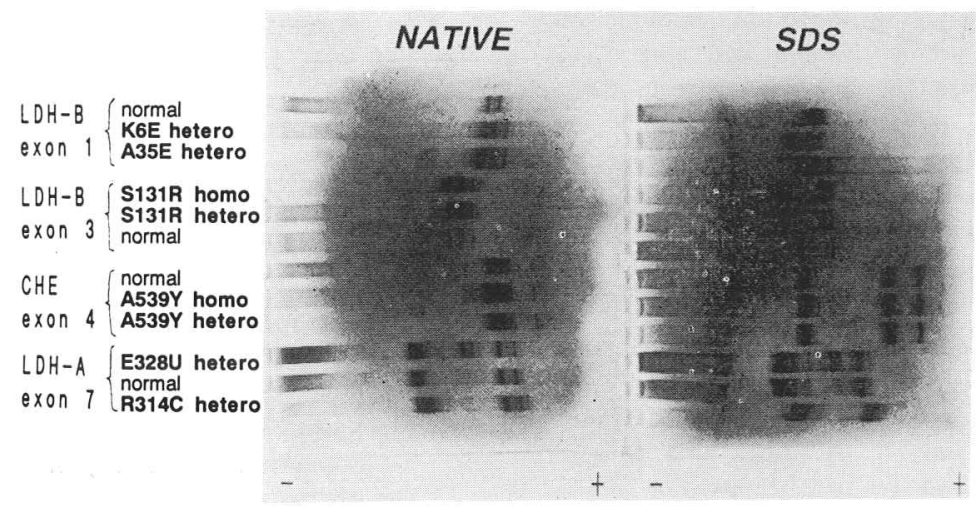

Fig. 4. An example of SSCP patterns on regular polyacrylamide gel electrophoresis. SSCP electrophoresis was performed under native and SDS buffers, using 12.5\% homogeneous gels $(9 \times 9 \mathrm{~cm}$, DAIICHI PURE CHEMICALS), at a constant current of $30 \mathrm{~mA}$ and at $8^{\circ} \mathrm{C}$. After electrophoresis, the gels were stained by the silver staining kit (Silver Stain. "DAIICHI"). 
かに簡単と考えられた。

結論として, SSCP 法で検出しやすいかしにくいかの 予測は現時点ではまだ可能ではない. どの条件で検出し やすいかは対象とする DNA 断片の塩基配列に左右さ れる. したがって，一つの泳動条件のみで変異の有無を 判定するのは危険である. サンプルどとに泳動用ゲルの 種類 (12.5\% homogeneous gel, 8〜25\% gradient gel), バッファー条件 (native, SDS), 泳動温度によって検 出効率が変わるため, 至適条件をみいだすととが重要で ある。われわれは, SDS は $15^{\circ} \mathrm{C}$, native は $10^{\circ} \mathrm{C}$ か $5^{\circ} \mathrm{C}$ で $12.5 \%$ homogeneous gel 用いて検出する のがよく, 小さな挿入・欠落の検出には 8～25\% gradient gel あ有用であると考え, 遺伝子変異の検出に適用 して複数の遺伝子異常をみいだしつつある.

本研究の一部は第 43 回電気泳動学会春季大会で報告 した. 本研究の一部は科学研究費 (No. 05671920, No. 05454583)によった.

\section{文献}

1) Orita M, Suzuki $Y$, Sekiya $T$, Hayashi $K$ Rapid and sensitive detection of point mutations and DNA polymorphisms using the polymerase chain reaction. Genomics $1989 ; 5: 874-9$.

2) 前川真人.〔ワークショップ: PCR とその応用〕 PCR による LDH サブュニット久損の解析. 生 物物理化学 $1992 ; 36: 367-71$.

3) Maekawa M, Sudo K, Li SS-L, Kanno T. Analysis of genetic mutations in human lactate dehydrogenase-A (M) deficiency using DNA conformation polymorphism in combination with polyacrylamide gradient gel and silver staining. Biochem Biophys Res Commun 1991 ; 180 : 1083-90.

4) Maekawa M, Sudo K, Kitajima M, Matsuura Y, Li SS-L, Kanno T. Detection and characterization of new genetic mutations in individuals heterozygous for lactate dehydrogenase-B $(\mathrm{H})$ deficiency using DNA conformation polymorphism analysis and silver staining. Hum Genet 1993; $91: 163-8$.

5) Maekawa M, Sudo K, Kitajima M, Matsuura $\mathrm{Y}$, Li SS-L, Kanno T. Analysis of a genetic mutation in an electrophoretic variant of the human lactate dehydrogenase-B $(\mathrm{H})$ subunit. Hum Genet 1993; 91: 423-6.

6) Orita $M$, Iwahana $H$, Kanazawa $H$, Hayashi $K$, Sekiya T. Detection of polymorphisms of human DNA by gel electrophoresis, as single- strand conformation polymorphisms. Proc Natl Acad Sci USA $1989 ; 86: 2766-70$.

7) Michaud J, Brody LC, Sttel G, Fontaine G, Martin LS, Valle D, Mitchell G. Strand-separating conformational polymorphism analysis : Efficacy of detection of point mutations in the human ornithine $\delta$-aminotransferase gene. Genomics 1992 ; $13: 389-94$.

8) Kishimoto M, Sakura H, Hayashi K, Akanuma Y, Yazaki Y, Kasuga M, Kadowaki T. Detection of mutations in the human insulin gene by single strand conformation polymorphisms. J Clin Endocrinol Metab 1992; 74 : 1027-31.

9) Hayashi K. PCR-SSCP : A simple and sensitive method for detection of mutations in the genomic DNA. PCR Methods Appl 1991; 1: 34-8.

10) Sudo K, Maekawa $M$, Ikawa S, Machida $K$, Kitamura M, Li SS-L. A missense mutation found in human lactate dehydrogenase $B(H)$ variant gene. Biochem Biophys Res Commun $1990 ; 168: 672-6$.

11) Sudo K, Maekawa M, Tomonaga A, Tsukada T, Nakayama T, Kitamura M, Li SS-L, Kanno $\mathrm{T}$, Toriumi J. Molecular characterization of genetic mutations in human lactate dehydrogenase $(\mathrm{LDH}) \mathrm{B}(\mathrm{H})$ variant. Hum Genet 1992 ; 89 : 158-62.

12) Sudo K, Maekawa M, Shioya M, Ikeda K, Takahashi N, Isogai Y, Li SS-L, Kanno T, Machida $\mathrm{K}$, Toriumi J. Molecular analysis of genetic mutation in electrophoretic variant of human lactate dehydrogenase-A $(M)$ subunit. Biochem Int $1992 ; 27: 1051-7$.

13）須藤加代子, 前川真人, 後藤はるみ, 小泉博史, 秋月摄子，真柄直郎，菅野剛史. DNA 解析によ り判明した血清コリンエステラーゼ K-変異の一 例. 生物物理化学 (印刷中).

14) Lee H-H, Lo W-J, Choo K-B. Mutational analysis by a combined application of the multiple restriction fragment-single strand conformation polymorphism and the direct linear amplification DNA sequencing protocols. Anal Biochem 1992; 205 : 289-93.

15) Savov A, Angelicheva D, Jordanova A, Eigel A, Kalaydjieva L. High percentage acrylamide gels improve resolution in SSCP analysis. Nucleic Acids Res 1992; 20 : 6741-2.

16) Maekawa M, Sudo K, Nagura K, Li SS-L, Kanno T. Population screening of lactate dehydrogenase deficiencies in Fukuoka Prefecture in Japan and molecular characterization of three independent mutations in the lactate dehydrogenase-B (H) gene. Hum Genet 1994 ; 93 : 74-6.

17) Pieneman WC, Reitsma $\mathrm{PH}$, Briet E. Double strand conformation polymorphism (DSCP) de- 
tects two point mutations at codon 280 (AAC $\rightarrow$ ATC) and at codon 431 (TAC $\rightarrow$ AAC) of the blood coagulation factor VII gene. Thromb Haemost 1993; 69 : 473-5.

\section{要旨}

$\mathrm{SSCP}$ 分析に影響を与える因子として，泳動支持体， バッファーの種類, 泳動温度を選択し, 全自動電気泳動 装置ファストシステムを用いて, 泳動パターンに及ぼす 影響を検討した．泳動支持体のなかでは $12.5 \%$ homogeneous gel を使用したとき最む遺伝子変異の検出率が
高く，SDS バッファーを用いた泳動条件で native の 条件に勝るとあ劣らない検出率を得た。ただ，変異の種 類によってはいずれかのバッファーに偏って至適条件を 示すあのも存在した. 温度もかなり劇的に泳動パターン に影響を及ばした．乙れらの泳動パターンは現時点で予 測できないため，一つの泳動条件のみで変異の有無を判 定するのは危険である．泳動用支持体の種類（12.5\% homogeneous gel, 8〜25\% gradient gel), バッファー 条件 (native, SDS), 泳動温度によって検出効率が変 わるため, 該当する変異に至適の条件をみいだすてとが 重要である. 